\title{
Befejezetlen proletarizáció? A vidéki munkaerő-tartaléksereg Magyarországon a 2008-as válságot követően.
}

\section{Incomplete proletarization? Rural reserve army of wage labour in Hungary after the 2008 crisis}

\author{
KOVAI CECÍLIA, VIGVÁRI ANDRÁS
}

\begin{abstract}
KOVAI Cecília: tudományos munkatárs, Társadalomtudományi Kutatóközpont, Kisebbségkutató Intézet; 1097 Budapest, Tóth Kálmán u. 4.; kovai.cecilia@tk.mta.hu ; https:// orcid.org/0000-0001-8153-0342

VIGVÁRI András: tudományos segédmunkatárs, Közgazdaság- és Regionális Tudományi Kutatóközpont, Regionális Kutatások Intézete; 1097 Budapest, Tóth Kálmán u. 4.; vigvari.andras@krtk.mta.hu; https://orcid.org/0000-0001-5181-7596
\end{abstract}

KULCSSZAVAK: munkaerő-tartaléksereg; félproletár háztartás; vidéki szegénység; háztartások túlélési stratégiái; munkaformák közötti mobilitás; közfoglalkoztatás; informális stratégiák

ABSZTRAKT: A magyarországi munkával kapcsolatos kutatások részletesen foglalkoztak a bérmunkából tartósan kirekesztett társadalmi csoportok munkaerőpiaci helyzetével, azonban jóval kevesebb figyelmet szenteltek a bérmunkán túli munkaformák szerepének vizsgálatára. Tanulmányunkban az általunk munkaerő-tartalékseregnek nevezett népesség megélhetési stratégiáit elemezzük a bérmunka, a közfoglalkoztatás, az alkalmi munka és az informális munka együttes vizsgálatán keresztül. Írásunkban azt állítjuk, hogy munkaerő-tartaléksereg népesség térbeli-társadalmi pozíciója miatt csak időszakosan, konjunkturális időszakokban kapcsolódik a bérmunkapiachoz, megélhetési stratégiája sokkal inkább a különböző munkaformák kombinálásán alapul. Tanulmányunkban hangsúlyozzuk, hogy munkaerő-tartaléksereget jelentő népesség nem az integrálatlanság, hanem sokkal inkább a kapitalista termelésbe való integráltság előnytelen helyzetét mutatja, megélhetési stratégiái, mobilitási aspirációi pedig a különböző munkaformák egymással való viszonyában értelmezhetők.

Cecilia KOVAI: research fellow, Institute for Minority Studies, Centre for Social Sciences; Tóth Kálmán u.4., H-1097 Budapest, Hungary; kovai.cecila@tk.mta.hu; https://orcid.org/0000-00018153-0342

András VIGVÁRI: junior research fellow, Institute for Regional Studies, Centre for Economic and Regional Studies; Tóth Kálmán u.4., H-1097 Budapest, Hungary; vigvari.andras@krtk.mta.hu; https://orcid.org/0000-0001-5181-7596

KEYWORDS: reserve army of wage labour; semi proletarian household; rural poverty; household livelihood strategy; labour mobility; workfare programs; informal strategies

ABSTRACT: In the 1990s, structural unemployment became one of the most crucial social problems of rural areas in Hungary. Even though after the 1990s the role of FDI and new industrial investment projects was significant, the geography of reindustrialization was extremely uneven. Typically, peripheral rural areas were left untouched by these investments, and thus unskilled workers of these areas could not entirely integrate into the formal labour market due to their

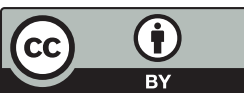


specific socio-spatial position. During the economic crisis of 2008, many of these unskilled workers were once again pushed out of the formal labour market, and even during the economic boom period after 2010 their social reproduction strategies remained diverse, including non-formal labour practices.

In our paper we investigate the structural position of this unskilled rural population, and we analyse how they combine different livelihood strategies during economic boom and crisis periods. We show that the livelihood strategies of unskilled workers in Hungarian rural areas are still based on multiple practices, such as day labour, informal labour and workfare programs. Since the connection of these unskilled workers to the formal wage labour market is not only vulnerable, but highly dependent on the cyclical waves of the economy, we define this population as the 'reserve army of wage labour market'.

While this 'reserve army of wage labour market' is only cyclically and partially integrated into the formal labour market, it still has a crucial and constitutive role to the capitalist system of production by providing cheap labour force at times when it is needed. As a result of this specific temporality of integration into the formal labour market, the members of the 'reserve army' are pressured to diversify their livelihood strategies. In the article we not only show how household strategies are adjusted to the cyclically changing economic context, but how juggling with different labour forms influence class, ethnic and labour relations in a complex way as well. Our findings are based on a three year long qualitative research conducted in rural regions of Hungary.

\section{Bevezetés}

A rendszerváltás utáni Magyarországon a foglalkoztatáshoz való hozzáférés és a munkanélküliség kiemelt kutatási területté vált a társadalomtudományokban (Ladányi, Szelényi 2004; Kertesi 2005; Szalai J. 2007; Kolosi, Tóth 2008; Köllő 2009). Ezt a kutatási trendet a 2008 utáni gazdasági válság nyomán egyre nagyobb teret nyerő közfoglalkoztatási programok csak tovább erősítették (Szőke 2015; Kovai 2016; Váradi 2016; Molnár et al. 2019). A kutatások többsége a rendszerváltás után tömegesen eltűnő munkahelyek társadalmi hatásaival, valamint a munkahelyteremtés és a térbeli-társadalmi felzárkózás lehetőségével foglalkoztak (Nemes Nagy, Németh 2003; Szalai J. 2007; Virág 2010). A kutatások kiemelt figyelmet szenteltek a munkával kapcsolatos társadalmi egyenlőtlenségek területi vonatkozásainak is, hangsúlyozva, hogy a periférikus földrajzi helyzetű, főleg falusias térségekben élők sokszorosan érintettek a formális munkaerőpiacról való kirekesztésben a központibb fekvésű, városiasabb térségek lakóihoz képest (Bihari, Kovács 2006; Virág 2010; Lőcsei 2010; Vidra 2013a).

A munka világával kapcsolatos hazai kutatások azonban leginkább a formális, állandó bérmunkára fókuszáltak, jóval kevesebb figyelmet szenteltek a bérmunkán kívüli megélhetési stratégiáknak, dacára annak, hogy a formális, állandó foglalkoztatásból kiszoruló népesség megélhetésében ezeknek a munkaformáknak történetileg is kitüntetett szerep jutott (Havas 1983; Tóth 1997; Fleck, Virág, Orsós 2000; Vidra 2013b; Durst 2017; Gagyi, Csányi, Kerékgyártó 2018; Danyi, Vigvári 2019). A szakirodalom nagy részében az is evidenciának tủnik, hogy e társadalmi csoportok előnytelen strukturális helyzetét a formális, állandó bérmun- 
ka rendszerébe való integrálatlanságuk okozza (Apró 2004; Ladányi, Szelényi 2004; Kertesi 2005; Babusik 2007; Köllő 2009; Bernáth 2014). Más kutatások ugyanakkor kimutatták, hogy ez a népesség lényegében az ipari vagy mezőgazdasági bérmunka tartalékseregeként szolgál, amelyet úgymond „hadra lehet fogni”, amikor a termelés munkaerőhiánytól szenved, de gond nélkül le is lehet építeni válságok idején (Szalai J. 2007; Czirfusz 2015; Kovai 2017; Vigvári, Gerőcs 2017; Czirfusz et al. 2019). Tanulmányunkban mi is munkaerő-tartalékseregként értelmezzük azt a formális, állandó bérmunkából kieső népességet, amely sajátos pozícióval és ciklikusan kapcsolódik a formális bérmunkapiachoz.

A nemzetközi munkakutatások tanulságai szerint a munkaerö-tartaléksereg sérülékeny strukturális helyzete nem a kapitalista termelésbe történő integrálatlanságból, hanem az előnytelen integráltságából fakad (Wallertsein 2000; Van der Linden 2001; Sanyal 2007; Dunaway 2018). A tartaléksereg-népesség integráltságának fő jellemzője, hogy a háztartások formális, állandó bérmunkához való hozzáférése nem állandó, ennek következtében megélhetésük nem támaszkodhat kizárólagosan az abból származó jövedelemre, hanem egyéb, bérmunkán kívüli munkaformákból kell beszerezniük a szükséges bevételeket. Habár a bérmunkán kívüli munkaformák a társadalmak széles rétegeiben megtalálhatóak, a szóban forgó népesség jóval inkább rákényszerül a különböző munkaformák kombinálására, hogy napi megélhetését biztosítsa. A háztartások mindennapi boldogulásához szükséges formális, állandó bérmunka és azon kívüli munkaformák ötvözése sajátos háztartási szerveződést kíván meg, melyet a szakirodalom félproletár háztartástípusnak nevez (Dunaway 2018).

Tanulmányunk éppen azt vizsgálja, hogy a munkaerő-tartaléksereg pozíciójában élő félproletár háztartások milyen megélhetési és mobilitás stratégiákat alkalmaznak a 2008-as válságot követő évtizedben. Cikkünkben arra keressük a választ, hogy a 2008-as gazdasági válság, illetve az azt követő fellendülés milyen változásokat okozott a magyarországi tartaléksereg-népesség megélhetési stratégiáiban, és azokban hogyan változott a különböző munkaformák (formális, állandó bérmunka, közfoglalkoztatás, alkalmi munka, informális munka) részesedése. Bemutatjuk, hogy különböző munkaformák milyen mobilitási mintázatokat hoznak létre az érintett félproletár háztartások életében. A fentiekkel párhuzamosan tanulmányunk azt is vizsgálja, hogy ezek a változások hogyan ágyazódnak be a helyi osztályviszonyokba, mely esetekben befolyásolják a háztartásokon belüli munkamegosztást, valamint miként alakítják az etnikai viszonyokat a lokális és tágabb társadalmi szinteken. Tanulmányunkban a háztartások különböző munkaformák közötti cirkulálását olyan stratégiaként értelmezzük, amely ugyan a strukturális helyzetből ered, mégis egyfajta mozgásteret is biztosít e népesség számára, amellyel az aktuális viszonyok között kedvezőbb helyzetet teremthetnek maguknak.

Megállapításainkat terepmunkáink megfigyeléseire, interjúira alapozzuk, amelyeket a 2010-es évek elejétől végeztünk az ország periférikus helyzetű falvaiban és kisvárosaiban, a hátrányos helyzetű népesség körében. ${ }^{1}$ Terepmunkáink 
alatt egyrészt a résztvevő megfigyelés módszertanával dolgoztunk, amely során a mindennapokban figyelhettük meg a szóban forgó népesség megélhetési stratégiáit, a munkaformákhoz társított értékek működését, valamint a háztartások döntési mechanizmusait. A kutatások során emellett több tucat interjút készítettünk az érintett háztartások tagjaival, munkaadókkal, a települések közfoglalkoztatásért felelős döntéshozóival. Habár az egyes települések méretük és térbeli elhelyezkedésük miatt más és más megélhetési lehetőségeket nyújtanak, mégis megfigyelhetőek olyan folyamatok (mint például a munkaformák váltogatása és annak irányai), amelyek a lokális sajátosságoktól függetlenül általános érvényünek tekinthetők. Tanulmányunk ezek bemutatásával és értelmezésével foglalkozik. Mindezek előtt azonban azt a kérdést vizsgáljuk, hogy a tartaléksereg-népesség koncepciója milyen tágabb összefüggések közé helyezi az általunk vizsgált népességet és ezek milyen tanulsággal szolgálnak számunkra.

\section{Az integrált kirekesztés: a munkaerő-tartaléksereg}

A munkaerő-tartaléksereg eredetileg Marxtól származó fogalom, amely a formális bérmunkából aktuálisan kívül rekedt munkanélküli népességre vonatkozik. A tartaléksereg kifejezés arra utal, hogy a munkanélküliség nem a kapitalista termelésből való kizáródást jelenti, hanem azt, hogy ez a népesség sajátos módon kapcsolódik a tőkefelhalmozáshoz. Valójában a munkaerő-tartaléksereg éppen részleges kizáratása által, olcsó, könnyen mozgatható és eldobható munkaerőként részese a tőkés rendszernek. E koncepció szerint a munkaerő-tartaléksereg léte alapvető feltétele a tőke felhalmozásának, a népesség reprodukciójának költségei ugyanis nem a tőkét terhelik állandó bérezés formájában, hiszen azt a formális, állandó bérmunkán kívüli munkaformák vagy különböző állami transzferek teszik lehetővé. A munkaerő-tartaléksereg koncepciója releváns értelmezési keretet nyújthat az általunk vizsgált népesség stratégiáinak feltárásához, hiszen - szemben a lokális és nemzeti léptékü kutatásokkal - szélesebb történeti, gazdasági folyamatok közé helyezi a formális, stabil bérmunkából kiszoruló rétegek vizsgálatát.

A munkaerő-tartaléksereg a globális szinten zajló egyenlőtlen munkamegosztás következményeként jön létre. Ez a népesség nincs kívül a kapitalista termelési rendszeren, csupán annak egy privilegizáltabb szegmenséből, a formális, állandó bérmunkából szorul ki részlegesen. A kiszámítható megélhetést biztosító formális, állandó bérmunka tulajdonképpen egy privilegizált munkaforma, amely a globális kapitalizmus előnyös pozícióiban élők számára hozzáférhető. Ezzel szemben a tartaléksereg-népesség pozíciójában élő félproletár háztartások mindig is különböző munkatípusok kombinálásával tartották fenn magukat (Wallertsein 2000; Van der Linden 2001; Sanyal 2007; Millar 2014; Dunaway 2018; Han 2018). E háztartások fő jellemzője, hogy megélhetésüket a formális bérmun- 
kából és azon kívüli tevékenységekből szerzett bevételekkel biztosítják, e kettő kombinációja pedig meghatározza a háztartáson belüli és a háztartások közötti viszonyokat. A félproletár háztartások megélhetési stratégiáival foglalkozó szakirodalom a különböző munkaformák ciklikus változásaira és e stratégiák összetettségére hívja fel a figyelmet (Hart 1973; Bourgois 2003; Grill 2015; Dunaway 2018; Han 2018; Millar 2018). E rétegek megélhetési stratégiájának legfőbb jellemzője a különböző munkaformák közti cirkuláció, amelyet a változó gazdasági ciklusok és az azokból fakadó egyéni élethelyzetek irányítanak (lásd Millar 2017). A munkatípusok közti cirkuláció eszerint olyan stratégiaként értelmezhető, amely egyfajta mozgásteret jelent a globális munkamegosztás előnytelen pozíciójában élők számára.

A munkaerő-tartaléksereg helyzetét mindig az egyenlőtlen munkamegosztás szélesebb összefüggéseiben érdemes értelmezni, nem feledkezve meg arról, hogy ez az előnytelen pozíció a lokális viszonyok között termelődik újra, amelynek megvannak az általános jellegzetességei. A munkaerő-tartaléksereg népesség újratermelődésében például a legtöbb társadalmi-történeti kontextusban kiemelt szerepet kap a térbeli és a „faji”/etnikai dimenzió, amelyek nagyban meghatározzák e népesség stratégiáit.

A munkaerő-tartaléksereggel foglalkozó szakirodalomban hangsúlyozzák, hogy e népesség társadalmi reprodukciójának mindig van térbeli vonatkozása is, hiszen a szóban forgó népesség jellemzően bizonyos szempontból periférikus terekben koncentrálódik (Bourgois 2003; Waquant 2008, 2012; Millar 2018; Rajaram 2018; Petrovici et al. 2019). Magyarországi kontextusban ezek elsősorban periférikus vidéki tereket jelentenek, olyan településeket, ahová a bérmunka expanziója csak erőteljes gazdasági konjunktúra idején ér el, így a különböző formális és informális munkaformák kombinálása elengedhetetlen a megélhetéshez (Kovách 2012; Kovai 2017; Németh 2019). Ugyanakkor e népesség számaránya és a különböző munkaformák megélhetésben játszott szerepe időben sem egységes: a gazdasági konjunktúrák időszakaiban, amikor nagyobb a munkaerő-kereslet, a bérmunka szerepe felértékelődik, míg a válságok alatt, amikor az elérhető bérmunka kevesebb, más munkaformák kerülnek előtérbe: informális munkák, alkalmi bérmunkák és a szociálpolitikai juttatások, vagy esetünkben az utóbbihoz kapcsolódó „workfare foglalkoztatás”.

Az elérhető formális bérmunka-lehetőségek térbeli szórtsága és időbeli hullámzása alapjaiban határozza meg a tartaléksereg-népesség térbeli-társadalmi mobilitási pályáit. Ahhoz, hogy egy vidéki háztartás közelebb kerüljön a jövedelmezőbb munkaformákhoz, költözni vagy ingázni kényszerül, amely számos költségvonzattal (idő, pénz, életmód és a családi élet szervezése) jár számukra. Ezzel szemben a periférikus, vidéki terek olcsó lakhatást és sokszor komplex megélhetési formákat nyújtanak, amelyek annak ellenére is vonzóbbak lehetnek, hogy a háztartások kevesebb pénzbeli jövedelmet tudnak megkeresni (Vigvári 2015). A periférikus terek azonban sok esetben az etnikai dimenzióval együtt válnak a tar- 
taléksereg-népesség strukturális helyzetét meghatározó jellemzővé (Virág 2010; Kovai 2017; Szombati 2018, Németh 2020).

Az egyenlőtlen munkamegosztás ugyanis együtt jár a rasszizálás/etnicizálás kirekesztő mechanizmusaival és a kulturális osztályozási sémákkal. A munkaerőtartaléksereg gyakran rasszizált vagy etnicizált népesség, vagyis faji/etnikai hovatartozásuk igazolja előnytelen osztálypozíciójukat, míg az állandó, formális bérmunka a jelöletlen fehérséggel, vagy a szintén jelöletlen többségi pozícióval kapcsolódik össze. A faji vagy etnikai kategóriák megszilárdítják az osztályhatárokat a viszonylag kiszámítható, állandó jövedelemmel rendelkező népesség és az abból részben vagy tartósan kiszoruló tömegek között (Quijano 2000; Wallertsein 2000; Boatca 2015; Rajaram 2018). Az osztályhelyzet rasszizálásnak/etnicizálásának e globális léptékben zajló folyamata kelet-európai kontextusban elsősorban „cigánykérdésként” jelenik meg (Effremova 2012; Kovai 2017; Rajaram 2017; Szombati 2018; Grill 2018; Petrovici et al. 2019). A rendszerváltás utáni Magyarországon a tartós munkanélküliség jelensége számos ponton összefonódott az ún. „cigányproblémával”, vagyis a tartaléksereg-népesség pozíciója a cigánysággal kapcsolódott össze. Mindez nem azt jelenti, hogy a munkaerő-tartaléksereg és a cigány származású népesség fedné egymást, hanem azt, hogy lokális kontextusban gyakran az számít cigánynak, aki ezt az előnytelen osztálypozíciót foglalja el (Vigvári 2013; Kovai 2017). Így van ez az általunk vizsgált vidéki terepeken is, ahol a formális, stabil foglalkoztatás inkább a többségi „magyar” pozícióhoz, míg a tartaléksereg-helyzet a cigánysághoz társul. Az etnicizált osztályegyenlőtlenségek azonban, mint láttuk, maguk után vonják a térbeli egyenlőtlenségek sajátos formáit is, hiszen ez a népesség jobbára olyan terekben koncentrálódik, amelyek „értéktelennek” minősülnek, esetünkben amúgy is periférikus helyzetü kisvárosok, falvak szegregált cigánytelepein, vagy a „gettósodó térségek” aprófalvaiban (Virág 2010; Kovách 2012; Váradi, Virág 2015). A tartaléksereg-népesség stratégiáit tehát mindig nagyban befolyásolják a térbeli és etnikai dimenzió fenti összefüggései, a munkaformák közti cirkuláció pedig többnyire együtt jár a térbeli és etnikai kategóriák közti mozgással is.

Ha a hazai munkaerő-tartaléksereg munkaformák közti cirkulációját vizsgáljuk, úgy tűnhet, mintha ez a népesség a proletarizáció felé vezető úton haladna, holott éppen ez az „átmeneti” állapot jellemzi stabil strukturális helyzetüket. Ennek ellenére a tartaléksereg-népesség saját percepciójában a formális, állandó bérmunkás létre való törekvés, vagyis a proletarizáció válik normává. Noha a félproletár háztartások számára is a formális, állandó bérmunka jelenti a „rendes munkát", és e népesség társadalmi mobilitással kapcsolatos vágyai a formális, állandó bérmunkás lét privilegizált pozícióját célozzák, esetükben sokkal inkább a több lábon állás és a különböző munkaformák kombinációja a magától értetődő mindennapi megélhetési gyakorlat, stratégiáik pedig a bérmunka ad hoc jelenlétéhez alkalmazkodnak. Ez a történetileg is felhalmozódó tapasztalat az, amely megélhetési stratégiáikat meghatározza, még azokban a gazdasági ciklusokban is, 
amikor úgy látszik, hogy a formális, állandó bérmunka expanziója felszámolhatja kedvezőtlen strukturális pozíciójukat. A következő fejezetben éppen azt járjuk körbe, hogy magyarországi kontextusban hogyan alakult a tartaléksereg-népesség helyzete és az milyen térbeli és etnikai dimenziókkal jellemezhető.

\section{A munkaerő-tartaléksereg magyarországi kontextusa}

\section{Történeti közelítések a magyarországi munkaerő-tartalékhadsereghez}

„A tőkés gazdasági rendszer egyik fő jellemzője a szabad bérmunka: miközben feloldja a feudális kötelékeket, egyre inkább »szabaddá« teszi a nincstelen falusi tömegeket”, és ennek során ,jellemző a falu és a város, a mezőgazdaság és az ipar között félúton megrekedt bérmunkások viszonylag nagy száma, akik megélhetésüket részben mezőgazdasági, részben pedig ipari üzemekben próbálják biztosítani, tehát kétlakiak" - írta Katona Imre a jobbágyfelszabadítás után elszegényedő paraszti csoportokról (Katona 1965, 382.). Az etnográfus megállapításából érzékletesen rajzolódik ki az a társadalomtörténeti folytonosság, amely a tartaléksereg-pozícióban élő félproletár háztartások megélhetési stratégiáit és a különböző munkaformák közötti cirkulációját mutatja.

Az 1950-es és 1960-as évek iparosítási hulláma korábban soha nem látott proletarizációs folyamatot indított el a magyar társadalom életében, amely a paraszti társadalom fokozatos felszámolódását és a háztartások egy részének városokba költözését eredményezte (Jávor et al. 2000). Az 1960-as és 1970-es években tetőző proletarizációs hullámot jórészt a világgazdaságban tapasztalható ipari konjunktúra táplálta, amely az 1970-es években bekövetkező globális válság nyomán a 1980-as évek végéig fokozatosan hanyatlásnak indult (Éber et al. 2014). Az 1970-es évek végétől „a teljes foglalkoztatás” ellenére a háztartások komplex megélhetési stratégiája - a bérmunka és a második gazdasághoz köthető informális munkavégzés kettőssége - terjedt el. A kutatások ezt a fajta „több lábon állást" a második gazdaság fogalmán keresztül össztársadalmi tapasztalatként írták le, amely azonban sokkal inkább érintette a vidéki népességet, amely a bérmunkapiachoz kedvezőtlenebb feltételekkel kapcsolódott, és a keresetkiesést a második gazdaságban végzett munkával kompenzálta (Nemes Nagy, Ruttkay 1989). Ezeket az átmeneti csoportokat újmunkásoknak (Kemény 1972), illetve utóparasztoknak (Márkus 1973) nevezte a szociológiai szakirodalom, utalva a háztartások különböző munkaformák közötti cirkulációjára. Az 1960-as évektől a bérmunkapiac alsó szegmenseibe fokozatosan integrált, zömében ugyancsak falusias térségekben lakó cigányok megélhetését pedig a hagyományos szerzőmozgó életformára épülő informális gazdaság, valamint a gyakran ingázásra épülő proletarizációs folyamatok együttállása jellemezte (Havas 1983). 


\section{Tartaléksereg a rendszerváltás után}

Noha az 1980-as évek második felére a bérmunkához való hozzáférés feltételei fokozatosan romlottak, a munkanélküliség a rendszerváltást követő években vált az egyik legégetőbb társadalompolitikai kérdéssé. Az 1990-es átmenet évei a munkaerőpiac és a munkásosztály szegmentálódását okozta, amelynek következtében a formális, állandó bérmunka a társadalom széles tömegei számára elérhetetlenné vált (Szalai J. 2007, 110.). A formális, állandó bérmunkához való hozzáférés feltételei ugyan az 1990-es évektől fokozatosan javultak, széles társadalmi csoportok számára továbbra is elérhetetlennek bizonyult a kiszámítható és stabil, szerződéses munkaviszony (Szalai E. 2001; Nemes Nagy, Németh 2003), amelyet az alsó-alávetett munkásosztályok prekarizálódó léthelyzete mutat (Éber 2020, 217.). Ennek következtében a formális foglalkoztatásból kirekesztett háztartások megélhetése elsősorban a szociális transzferjövedelmeken (mindenekelőtt a különböző szociális segélyek), valamint az alkalmi és informális munkaformákból szerzett bevételek kombinálásán alapult (Szalai J. 2007; Vidra 2013a; Kovai 2017).

A kutatások alapján a bérmunkapiac szegmentációjának vesztes társadalmi csoportjait elsősorban képzettségük és lakóhelyük különböztette meg a többségtől (Kolosi, Tóth 2008). A képzetlen munkaerő derékhadát a korábban is nagyobb számban ingázó munkások alkották, akik távolabbi, periférikus helyzetủ falvakból jártak az ipari központokba dolgozni. A rendszerváltás utáni tömeges bezárások miatt elveszítették munkájukat, kiszorultak a városi terekből, és szülőfalujukba költöztek vissza, ahol munkanélküliként a munkaügyi és szociális ellátórendszerre, illetve a helyben és a szükebb régióban fellelhető alkalmi és informális munkalehetőségekre támaszkodhattak. A bérmunkapiac szegmentációjának területi folyamatait és térbeli-társadalmi vonatkozásait több kutatás kimutatta (Schwertner 1994; Fazekas 1997; Nemes Nagy, Németh 2003). A szegmentáció területiségének legfőbb alapja, hogy a magyarországi térségek nagyon különbözően reagáltak a piacgazdasági átmenet gazdasági kihívásaira, amely erőteljesen formálta és erősítette az országon belüli területi egyenlőtlenségeket (Nemes Nagy, Németh 2003, 3.).

A rendszerváltás utáni munkaerőpiaci kutatások rámutattak az iskolázottság és a cigányokkal szembeni etnikai alapú diszkrimináció foglalkoztatásra gyakorolt erőteljes hatására is (Ábrahám, Kertesi 1996; Fleck, Messing 2009). Ábrahám és Kertesi kutatásaik alapján arra jutottak, hogy az általuk vizsgált időszak egészében a cigány népesség aránya, illetve az átlagos iskolázottsági szint bizonyult a regionális munkanélküliségi különbségeket alakító döntő tényezőnek, és hogy a cigány népesség aránya közvetett módon az adott terület gazdasági elmaradottságát is méri $(1996,673$.$) .$ 


\section{Tartaléksereg a 2008-as gazdasági válságot követö konjunktúra időszakában}

A 2008-as válság érzékenyen érintette a hazai bérmunkapiacot, 2010-ig közel 200 ezer munkahely szűnt meg szerte az országban. A 2010 utáni foglalkoztatási mutatók gyors ütemü javulása is országos trendnek bizonyult, amely az iparosodott, központibb fekvésü területeken a bérmunka expanzióját jelentette. A periférikus vidékeken viszont a korábbi segélyezési rendszert felváltó, 2008-ban bevezetett, 2011-ben átalakított, majd 2013-tól látványosan kiterjesztett workfare alapú közfoglalkoztatási programok következtében statisztikai értelemben csökkent a munkanélküliség, ami látványosan javította az évtizedek óta kedvezőtlen foglalkoztatási mutatókat (Molnár et al. 2019). A 2015-öt követően kibontakozó gazdasági konjunktúra azonban a rendszerváltás óta nem látott foglalkoztatási bővülést okozott: a munkaügyi központokban bejelentett üres állások havi átlagos állománya 2015-2016-ban a rendszerváltás óta nem tapasztalt szintre emelkedett (Köllő, Nyírő, Tóth 2017).

A rekordszintre növekedett bérmunka-kereslet a tartósan munkanélküliséggel sújtott térségekben is éreztetni kezdte a hatását. A korábban jobbára közfoglalkoztatásra, alkalmi és informális munkára berendezkedett tartaléksereg-népesség a 2010-es évek második felében egyre nagyobb számban lépett be a bérmunkapiacra, amely a mobilitási és aspirációs mintázatok gyors átrajzolódásához vezetett. A közfoglalkoztatás 2016-ban érte el csúcspontját, amelyet a programok leépítése és a programokból való gyors kilépések követtek. A viharos sebességgel változó gazdasági és foglalkoztatási helyzet a közpolitikai intézkedések gyors váltakozásában és az egyre összetettebb háztartási stratégiákban is tetten érhető volt. Ezeket a stratégiákat egyre inkább a formális, állandó bérmunka, az egyre szükülő közfoglalkoztatás, valamint az alkalmi és informális munkák széles választéka közötti cirkuláció jellemezte.

\section{A munkaerő-tartaléksereg megélhetési stratégiái a 2008-as válság után}

A fenti fejezetekben bemutattuk, hogy a bérmunka expanziója történetileg rendkívül nagy térbeli-társadalmi egyenlőtlenségeket mutat Magyarországon, amelyek bizonyos társadalmi csoportokat (munkaerő-tartaléksereg) és térségeket (vidéki, periférikus területek) kiemelten sújtanak. Írásunkban azonban a foglalkoztatási egyenlőtlenségekre fókuszáló megközelítésekkel szemben nem kizárólag a bérmunkához füződő viszonyon keresztül elemezzük az általunk vizsgált félproletár háztartások megélhetési stratégiáit. Ellenkezőleg, azt állítjuk, hogy e népesség megélhetési stratégiái sokkal inkább a különböző munkaformák közötti mozgásban ragadhatóak meg, amelyek biztosítják a családok szükös megélhetését, munkaerőpiaci kirekesztettségük dacára. 
E fejezetben kutatásunk empirikus eredményeit közöljük, és a háztartások szemszögéből kívánjuk bemutatni a tartaléksereg-népesség 2008-as válságot követő megélhetési stratégiáit. Az általunk vizsgált időszak különösen érdekes, hisz rövid időn belül a bérmunkapiac beszűkülése majd az expanziója teremtett változásokat, amelyek gyors alkalmazkodási készséget és összetett stratégiákat kívántak meg a háztartásoktól. Elemzésünkben sorra vesszük azokat a munkaformákat, amelyek az általunk vizsgált háztartások „munkavállalói portfólióját” jellemzik, és megvizsgáljuk, hogyan és miként alkalmazzák ezeket az eltérő kereseti formákat megélhetésük biztosításában. Írásunk további részében az általunk azonosított négy domináns formát, (1) a munkaszerződésen alapuló formális és stabil bérmunkát, (2) a helyi önkormányzat által megszervezett közfoglalkoztatást, (3) a legális keretek között végzett alkalmi foglalkoztatást, és (4) az informális megélhetési stratégiákat vizsgáljuk. A következő alfejezetekben a háztartások szemszögéből vesszük sorra a munkaformák jellemzőit, egymáshoz való viszonyát, előnyeit és hátrányait. Elemezzük, hogy ezekben az összetett stratégiákban hogyan jelenik meg a térbeli-társadalmi mobilitás lehetősége, és általában véve a helyi etnikai és osztályviszonyok újratermelése.

\section{A formális, állandó bérmunka}

A vidéki tartaléksereg megélhetési portfóliójában a formális, állandó bérmunka jóval inkább egyfajta távoli vágyként, mintsem konkrétan elérhető lehetőségként volt jelen a rendszerváltást követő évtizedekben. Az idősebb generáció számára az állandó bérmunkás életforma még személyes tapasztalat volt, amely a Kádár korszak „kiszámítható világában” gyökerezett. A rendszerváltás után felnövő generáció portfóliójának már sokkal inkább az alkalmi, informális munkából származó eseti bevételek és az egyre szúkülő szociális ellátásokkal való zsonglőrködés vált szerves részévé, a bérmunka csak időszakosan elérhető, privilegizált lehetőség maradt (lásd Vidra 2013a; Kovai 2017). Fontos azonban hangsúlyozni, hogy esetünkben a tartaléksereg többnyire etnikailag is stigmatizált státuszt jelent, vagyis a cigánysághoz társul, míg a formális, állandó bérmunka inkább az etnikailag jelöletlen „munkás” pozícióját hozza létre. A bérmunkához való kapcsolódás nem pusztán a társadalmi felemelkedés legevidensebb formája lesz e csoportok számára, hanem a cigányság rendkívül stigmatizáló, bántó jelentéseitől való megszabadulás esélyét is hordozza (Vidra 2013a; Kovai 2019).

A 2015-öt követő időszakban a gazdasági konjunktúra felfutásával a rendszerváltás óta nem látott mértékű növekedés mutatkozott a betöltetlen álláshelyek mennyiségében, amelynek következtében felértékelődött a távoli vidékeken élő félproletár háztartások szerepe az álláshelyek betöltésében (Köllő, Nyírő, Tóth 2017). A nagyszámú, üres, betöltetlen álláshelyek ellenére még 2018-ban is magasabb volt azok száma, akik a statisztikák szerint nem tudtak elhelyezkedni, tehát a munkaerőhiány és a munkanélküliség egyidejü jelenlétéről beszélhetünk 
(Bakó, Lakatos 2019). A munkáltatói és közpolitikai oldalról első látásra egymásnak ellentmondó folyamatokat illetően azonban a háztartásokkal készült interjúink számos racionális magyarázattal szolgálnak arról, hogy a bérmunkapiacra való belépésnek milyen lehetőségei és korlátai vannak, amelyek segítik a fenti, látszólag ellentmondásos gazdasági és társadalmi jelenségek mélyebb megértését.

A formális, állandó bérmunka, amellett, hogy egyértelműen a leginkább vágyott és legnagyobb presztízzsel járó foglalkoztatás, a munka törvénykönyvének 2012-es lazításai ellenére is (lásd Ferge 2017) a legbiztonságosabbnak tekinthető munkaforma, hiszen a felek között szerződés születik a foglalkoztatás feltételeiről. A bérmunkás munkaviszonnyal és a járulékfizetéssel a munkavállaló jogosultságot szerez a társadalombiztosítás alapú ellátásokra (nyugdíj, táppénz, illetve a munkaviszony megszűnésével a munkanélküli ellátás). Munkavállalói szemszögből a legfontosabb ezek közül az egészségügyi ellátásokhoz való hozzáférés, ahogy több interjúalany megfogalmazta, , a legfontosabb, hogy zölden világitson a lámpa, amikor baj van", és orvoshoz kell menni.

A bérmunkás életforma a társadalmi mobilitás fontos előfeltételét képezheti az általunk vizsgált, immobil népesség életében. A formális, állandó bérmunka egyrészt viszonylag magas jövedelmet biztosít, amelynek összege az elmúlt években a növekvő munkaerőhiány következtében folyamatosan emelkedett. A háztartások történetei arról tanúskodnak, hogy a munkavállalók a rendszerváltás óta nem látott alkupozícióba kerültek, s hogy a béralkuhelyzet javulásával és a folyamatos túlórázással bevételeik jelentősen emelkedtek. A munkaszerződés által nyújtott másik előny, hogy a háztartások hitelképessé válhatnak a pénzintézeteknél, ezáltal jogosultak lesznek hitelfelvételre és az állam által nyújtott otthonteremtési támogatások széles körére, amellyel képessé válhatnak a (mind a komfortfokozat, mind a földrajzi elhelyezkedés tekintetében) kedvezőbb lakáskörülmények megteremtésére (Bródy, Pósfai 2020).

A formális, állandó bérmunka azonban komoly áldozatokat is követel a háztartásoktól, amelynek elsődleges oka az, hogy a rendelkezésre álló bérmunka-lehetőségek földrajzilag távol helyezkednek el a tartaléksereg-népesség periférikus lakóhelyeitől (Meszmann 2019). Az általunk vizsgált népesség számára az elérhető munkahelyek napi többórás ingázással vagy „heteléssel” (heti ingázással és munkásszállókon megoldott lakhatással) érhetők el, ami komoly terhet jelent a háztartások életében, és megnehezíti azt, hogy a háztartás összes tagja a bérmunkapiachoz kapcsolódjon. Ennek kutatásaink alapján az a következménye, hogy újratermelödnek a háztartáson belüli munkamegosztás hagyományos szerepei, azaz a férfiak huzamosabb ideig a családtól távol dolgoznak, míg a nők háztartásbeliként vagy közfoglalkoztatottként helyben maradnak, betöltve a reproduktív munkákban betöltött klasszikus szerepüket (Váradi 2020).

Kutatásunk meglepő tanulsága azonban, hogy a formális bérmunkaviszony néhány esetben gyengíti a munkavállaló egzisztenciális biztonságát, ami alapvetően e népesség eladósodottságával függ össze. A hatóságok ugyanis a nem telje- 
sítő hitelek törlesztőrészleteit a formális munkaviszonyból származó bérből tudják levonni. Sokan ezért utasítják vissza az állandó, formális munkaszerződést, hiszen a napi bejelentésen alapuló alkalmi munkavállalás és az informális jövedelmek esetén a hatóságok nem tudják levonni tartozásaikat a fizetésükből. Terepmunkánk másik tanulsága, hogy a változatos megélhetési formákhoz igazodó népesség számára nem is feltétlenül vonzó a hosszútávú elköteleződés egy munkáltatóhoz, hisz a háztartások megélhetési portfóliói évtizedeken át a „több lábon állásra" épültek. Tapasztalatainkból az rajzolódik ki, hogy a háztartások az egy munkáltatótól való függést nem biztonságként, sokkal inkább függőségként értelmezik. Ha a háztartásfő szerződést köt egy távoli céggel, ahova ingázni kényszerül és teljesíti az egyébként viszonylag jól fizető műszakokat, fel kell adni azokat a lokálisan bejáratott megélhetési formákat és kapcsolatokat, amelyek válságidőszakokban a család megélhetését biztosítják. A szerződéses garanciával folyósított havi munkajövedelmet így, a pénzösszegtől függetlenül, gyakran bizonytalanabbnak tartják, mint az informálisan vagy heti alkalmi munkákkal megkeresett kisebb jövedelmek összességét, amely meggátolja a formális és stabil bérmunkával szembeni elköteleződést.

\section{A közfoglalkoztatás}

A közfoglalkoztatás a munkaerő-tartaléksereget érintő legmeghatározóbb közpolitikai intézkedés volt a 2008-as válság után, amely a tartós munkanélküliség problémájának kezelése mellett a vidéki terekben felhalmozódó, osztályalapú „etnikai” feszültségek pacifikálását is szolgálta. A közfoglalkoztatás 2009-től fokozatosan váltotta fel a segélyezés rendszerét, így a háztartások megélhetési portfólióiban a legfontosabb biztos bevételi forrássá vált a válság éveiben. Habár a közfoglalkoztatás állami transzferként közvetlenül nem illeszthető a tőke-munka viszonyba, ugyanakkor mind funkciójában, mind a foglalkoztatottak számára munkaként jelenik meg. Értelmezésünkben a közfoglalkoztatás olyan, a helyi önkormányzatok által megszervezett állami foglalkoztatás, amely a formális, állandó bérmunka ethoszát, normáját érvényesíti azokban a periódusokban is, amikor a gazdasági helyzet ezt a munkaformát nem, vagy csak szűkösen teszi elérhetővé a félproletár háztartások számára. Ilyen értelemben a közfoglalkoztatás mint tipikus workfare program olyan fegyelmező eszköz, amely a formális, állandó bérmunka normatív hegemóniáját tartja fenn egy olyan népesség körében, amely strukturális helyzete következtében csak részlegesen fér hozzá ehhez a munkaformához (Kovai 2019).

A közfoglalkoztatást mint foglalkoztatáspolitikai eszközt számos kritika érte azért, mert nem bizonyul hatékony eszköznek a tartós munkanélküliek elsődleges munkaerőpiacra való visszavezetésében, ehelyett ezt a népességet a helyi hierarchikus viszonyokba zárja be, amelyeknek szerves része az etnikai stigmatizáció (Csoba 2010; Virág, Zolnay 2010; Scharle 2012; Asztalos-Morell 2014; Szikra 
2014; Kálmán 2015; Váradi 2016; Ferge 2017). E “sikertelenség” nem tűnik meglepőnek, ha elfogadjuk azt, hogy a közfoglalkoztatás egyik legfőbb funkciója a formális, állandó bérmunka ethoszának fenntartása, nem pedig a munkaerőpiac átrendezése. A kritikák mellett azonban számos írás született a közfoglalkozatási programok mindennapi gyakorlatairól, amelyek arra mutattak rá, hogy a közfoglalkoztatás megvalósítása nagyban igazodik a lokális viszonyokhoz (Asztalos-Morell 2014; Szőke 2015; Kovai 2016; Váradi 2016; Gerő, Vigvári 2019). Kutatásaink is alátámasztották a lokális viszonyok jelentőségét a közfoglalkoztatás megvalósításában: míg vannak olyan települések, ahol valóban a hierarchikus osztály- és etnikai különbségtétel kirekesztő mechanizmusait erősítő eszköz, másutt teret ad a társadalmi integráció és szolidaritás különböző formáinak is. A közfoglalkoztatáson alapuló munkaviszony esetén fontos szerepet kap a lokalitás, hiszen úgy „tartja fogva” a tartaléksereg-népességet, hogy közben minimális egzisztenciális biztonságot nyújt, többek között a közfoglalkoztatotti munkaviszony révén, amely ugyan a minimálbérnél alacsonyabb fizetést biztosít, de egészségügyi és egyéb ellátásokat is magába foglal.

Közvetlenül a válság utáni években a közfoglalkoztatás lett a legmeghatározóbb munkaforma a félproletár háztartások megélhetési stratégiáiban, mivel a többi lehetőség kockázatosabbnak és elérhetetlenebbnek bizonyult a periférikus térségekből. A közfoglalkoztatás a munkaerő-tartaléksereget a lokális viszonyokhoz köti, hiszen a közfoglalkoztatott pozíciók elosztása felett a helyi vezetés rendelkezik, így a közmunkásállás megszerzése a helyi vezetéssel kialakított kapcsolattól függ. A közfoglalkoztatás a válság éveiben úgy biztosított bevételi forrást a háztartások számára, hogy közben megerősítette a helyi osztályviszonyokat, etnikai különbségtételeket, s ezzel az egyenlőtlenségek újratermelődését segítette, ám egyúttal a helyi társadalmi viszonyok megtartó erejét is növelte. Nem véletlen, hogy az érintett népesség számára a közfoglalkoztatás egyszerre jelent biztonságot és kényszert, ami visszatükrözi a lokalitás szerepének fenti ambivalenciáit.

2015-től kezdve, a gazdasági konjunktúra beköszöntével a közfoglalkoztatás egyre inkább vesztett jelentőségéből a háztartások megélhetési portfóliójában, és ez a munkaforma funkcióját is átalakította. Több interjúalanyunk, aki 2015-ben közfoglalkoztatottként dolgozott, a 2010-es évek végére gyári munkás lett, hiszen az égető munkaerőhiány következtében a gyárak buszai olyan periférikus falvakba is elértek, ahol erre korábban nem volt példa. Sokaknak ez volt az első tapasztalata a gyári munkáról, az azzal járó viszonylag magas, kiszámítható jövedelemről, ugyanakkor az előző alfejezetben bemutatott kedvezőtlen feltételekről is. A közfoglalkoztatás immár nem annyira a megélhetés miatt szükséges kényszer, mint inkább választható lehetőség, ugyanakkor ez a választás a formális, állandó bérmunkába történő bekapcsolódás kedvezőtlen feltételeivel áll összefüggésben. A közfoglalkoztatás válság utáni funkciója leginkább a formális, állandó bérmunkával való viszonyban érthető meg, amely a háztartásokon belüli munkamegosztást is 
befolyásolja. A formális, állandó bérmunka expanziójának területi sajátosságai miatt a munkavállalás többnyire együtt jár a napi ingázás anyagi és érzelmi költségeivel. Emellett ezek a munkahelyek gyakran három müszakos munkarendet vagy 10-12 órás munkanapokat kínálnak dolgozóiknak a közfoglalkoztatáshoz képest magas jövedelemért cserébe. Ezek a körülmények mindkét szülő elhelyezkedése esetén megnehezítik a mindennapok megszervezését és kihívás elé állítják a családokat.

A munka és a család összeegyeztetésének dilemmáját a közfoglalkoztatás segítségével a nemek közti munkamegosztás oldja fel. A válság utáni években föként azok a nők maradtak a közfoglalkoztatásban, akikre a családban gondozási feladatok is hárulnak (Váradi 2020). A helyben rendelkezésre álló, napi nyolc órás közfoglalkoztatás egy müszakos munkarendet jelent, alacsony, de biztos jövedelmet nyújt, az informális viszonyok révén pedig könnyebben illeszthető a háztartások napirendjéhez. Nem véletlen, hogy egy kisvárosi közmunkaprogramot koordináló munkatárs a közfoglalkoztatást ,a környék egyetlen családbarát munkahelyeként" írta le. Jó példák erre azok az esetek is, amikor a közfoglalkoztatásban dolgozók munka mellett is gond nélkül intézhetik hivatalos ügyeiket: ha orvoshoz kell menniük, ha a gyerekekkel váratlanul történik valami, vagy csak egyszerüen egyéb hétköznapi elfoglaltságuk adódik, általában elkéredzkedhetnek a munkavezetőtől. Ennek a kedvező pozíciónak minden bizonnyal az az oka, hogy a bérmunka expanziója amúgy is jelentősen megnövelte a közfoglalkoztatottak alkupozícióját, mivel az utóbbi években a helyi vezetésnek egyre nehezebb feltölteni a helyeket. Ezek a feltételek arra ösztönzik a háztartásokat, hogy azok a nők, akikre a neveléssel, gondozással összefüggő feladatok hárulnak, a közfoglalkoztatásban helyezkedjenek el, aminek következtében a félproletár háztartások megélhetési portfóliójában a formális, állandó bérmunka és a közmunka a gazdasági konjunktúrát követően is több esetben szimbiózist alkot. A közfoglalkoztatás azoknak is vonzó lehet, akik más okokból (például egészségi állapotuk, életkoruk, vagy a rossz közlekedés miatt) nem tudják, vagy nem akarják vállalni az elsődleges munkaerőpiacra való visszatérést. A közfoglalkoztatotti státusz betöltése tehát olyan munkavállalói stratégiaként is értelmezheto", amely kijátssza a formális, állandó bérmunka kedvezőtlen feltételeiből fakadó kényszereket, vagy legalábbis élhetőbbé teszi azokat a háztartások számára.

\section{Az alkalmi munka}

A rendszerváltás után a vidéki tartaléksereg-népesség számára leginkább elérhető munkaformává az alkalmi foglalkoztatás vált, amely szezonálisan, illetve az adott munkáltató gazdasági lehetőségeihez mérten biztosít hosszabb-rövidebb foglalkoztatási formát azoknak, akik nem tudnak az állandó, stabil bérmunkapiachoz kapcsolódni. Az alkalmi foglalkoztatók tipikusan lokálisan beágyazott kisés középvállalkozások, akik gazdasági erejükből és profiljukból adódóan nem tud- 
ják/akarják vállalni a huzamosabb foglalkoztatást, időszakosan azonban nagyobb munkaerőigénnyel is rendelkezhetnek. Tipikusan ilyen munkaformák a szezonális mezőgazdasági, illetve a szolgáltató szektorban (főként a vendéglátásban) fellelhető, és az építőiparhoz köthető tevékenységek.

A rendszerváltás éveit követően az alkalmi munka jobbára az informalitás szférájába tartozott, majd fokozatosan kialakították a rá vonatkozó munkáltatói szabályrendszert, így mára az atipikus foglalkoztatás legális formájává vált. Az egyszerüsített foglalkoztatási jogviszony célja, hogy a munkáltató számára a leginkább rugalmas foglalkoztatási kereteket teremtsen és ösztönözze arra, hogy az időszakos munkavállalókat ne feketén, hanem legálisan foglalkoztassa. Az egyszerűsített foglalkoztatás keretében a munkáltató egy összegben, egy napra fizeti a járulékokat a munkáltató után, a munkavállalóval nem köt munkaszerződést, és az adott foglalkoztatás időtartama mindig csak egy napra szól.

Munkavállalói szemszögből az alkalmi foglalkoztatás a bérmunkához és a közfoglalkoztatáshoz képest is egyértelműen kisebb biztonságot nyújt. Az egyszerűsített foglalkoztatás alacsony járulékköltségei következtében a munkáltató nem fizeti az alkalmi munkavállaló után az egészségügyi hozzájárulást, így az betegség esetén nem jogosult táppénzre. A ledolgozott napok beleszámítanak a nyugdíjba és a munkanélküli ellátásra való jogosultságba is.

Habár foglalkoztatáspolitikai szempontból az egyszerüsített foglalkoztatás a leginkább kiszolgáltatott legális munkaviszonyt jelenti a munkavállalók számára, kutatásunk egyik legmeglepőbb tanulsága szerint sokszor maguk a háztartások részesítik előnyben ezt a foglalkoztatási formát. Ennek egyik oka, hogy 30 ledolgozott nap után a dolgozó - a közfoglalkoztatáshoz hasonlóan - jogosult lehet a foglalkoztatást helyettesítő támogatás igénybevételére. Terepmunkánk tapasztalatai szerint ez az egyik fontos vonzó tényező az egyszerűsített foglalkoztatást választók körében, hiszen a foglalkoztatást helyettesítő támogatást, alacsony összege ellenére, megélhetési portfóliójuk egyik legbiztosabb bevételi forrásának tartják. Az alkalmi munka vonzerejének másik oka a háztartások eladósodottságában keresendő, ugyanis a magas nem teljesítő hiteleket a napi bejelentéses formájú egyszerüsített foglalkoztatás esetén a végrehajtók nem tudják levonni (Bródy, Pósfai 2020). Az alkalmi munkavállalás mellett szóló harmadik indok az, hogy a gyakran váltogatott munkahelyekkel lehetőség nyílik a kedvezőbb bér kiharcolására. A munkavállaló által kiharcolt magasabb bér tapasztalataink szerint meglehetősen „illékony”, ugyanakkor a munkavállaló, a munkáltatóval kötött megállapodás esetleges megszegésével, munkaszerződés hiányában is azonnal válthat egy általa jobbnak ítélt, újabb átmeneti pozícióra.

A napi bejelentéses alkalmi foglalkoztatás emellett kevesebb elköteleződést kíván meg a munkáltatótól, tehát a bérmunkával ellentétben sokkal szervesebben illeszkedik a félproletár háztartások több lábon álló megélhetési portfóliójába, ahol a háztartások az elérhető lehetőségeket mérlegelve, rugalmasan döntenek egy-egy aktuálisan „megfogható” munka mellett. A napi bejelentés további elő- 
nye, hogy a munkaadó általában azonnal, aznap fizet. Tapasztalataink szerint ez biztonságot nyújt a dolgozónak, aki számít arra, hogy valóban kifizetik a munkáját, ugyanakkor jobban is illeszkedik a családok gazdálkodási stratégiáihoz, hisz a háztartások nagy része egyáltalán nem rendelkezik megtakarításokkal.

Az alkalmi munka világa jellemzően szorosan kapcsolódik a lokalitáshoz, hiszen a sikeres munkaszervezés a személyes ismeretségen és a lokális közösségekbe való beágyazottságon alapul. Noha az elvégzendő munka több esetben is nagyobb távolságra található, a munkaszervező gazda vagy brigádvezető általában a lokális közösség kiemelkedett tagja, akinek egyik legfontosabb készsége éppen a megfelelő munkaerő folyamatos toborzása. A toborzásnál és a munkavégzésnél kiemelt szerep jut a rokoni és szomszédsági kapcsolatoknak, s így e munkaforma a helyi etnikai és osztályviszonyok folyamatos újrateremtését szolgálja. Az alkalmi munka tehát aligha járul hozzá a dolgozók társadalmi mobilitásához, jóval inkább etnikai és osztálypozíciójuk megszilárdítását eredményezi.

\section{Az informális munka}

Informális munkának azokat a pénzkereseti tevékenységeket tekintjük, amelyekben a részvevőket nem köti egymáshoz semmiféle hivatalos szerződéses viszony. A munkavégzés a mindenkori állami szabályozás keretein kívül történik, amit a felek közötti személyes megállapodások, informális kapcsolatok szabályoznak. Az informális pénzkereseti tevékenységek az államszocialista „teljes foglalkoztatás” időszakában sem tűntek el, és szerepük a gazdasági konjunktúra idején sem szorul teljesen háttérbe (Havas 1983; Tóth 1997; Fleck, Orsós, Virág 2000; Vidra 2013b). Az informális munkák palettája jelenleg is igen széles, fajtái a ház körüli munkák elvégzésétől a különböző kereskedelmi tevékenységekig terjednek. Ezek a munkák azonban csak ritkán fedezik a háztartás megélhetését és meglehetősen bizonytalan bevételi forrást jelentenek, egyes esetekben pedig egyéb, fóként szabálysértési kockázatot is hordoznak magukban. Ennek következtében csak kevés háztartás támaszkodik elsődlegesen erre a munkaformára, megélhetési portfóliójukban többnyire kiegészítő jövedelmeként jelenik meg. Az informális munkaformák szerepe válság idején felértékelődik, a gazdasági konjunktúra esetén, a bérmunka expanziójával pedig visszaszorul, hiszen ilyenkor a háztartások a biztos jövedelmet nyújtó bérmunkát részesítik előnyben. Ugyanakkor tereptapasztalataink azt mutatják, hogy az informális munkaformák ilyenkor is fontos tételt jelentenek a háztartások megélhetési portfólióiban, hiszen mint láttuk, a formális, állandó bérmunka csak korlátozott feltételek között érhető el. Az informális munkákat a háztartás azon tagjai végzik, akik a háztartáson belüli tevékenységekben kevéssé érintettek, így akár más munkaformák mellett is marad szabad kapacitásuk: például nyugdíjas korú nők vagy gyermektelen, fiatal férfiak.

Az informális munkák széles skálán mozognak, egymástól nagyon különböző viszonyrendszerekben jönnek létre, ezért eltérő típusú társadalmi kötődéseket 
és különbségtételeket teremtenek és erősítenek meg. A félproletár háztartások körében elterjedt tipikus informális munka például a mindenféle ház körüli feladatok elvégzése a magasabb státuszú lakosoknál/családoknál. Az ilyen jellegü informális munka nagyfokú bizalmat követel meg a felek részéről, ez a bizalom azonban nem pusztán a személyes ismeretségből táplálkozik, hanem sok esetben a helyi patrónus-kliens típusú kapcsolatok történetében gyökerezik (Durst 2008). A patrónus-kliens viszony a hierarchikus cigány-magyar különbségtétel sajátja az általunk vizsgált falvakban, következésképpen ez a munkaforma a bizalmi kapcsolattal együtt az osztályalapú etnikai különbségtétel otthonos hierarchiáját is erősítheti a felek között.

A fentiekhez képest teljesen más jellegű viszonyokat generálnak a különböző informális kereskedelmi és gyüjtögető tevékenységek. Ezek a munkák azok, amelyek a leginkább kikezdik a formális, állandó bérmunka ethoszára épülő helyi középosztály értékrendszerét, amely sok esetben etnikailag stigmatizálja és illegitim pénzkereseti módnak tekinti e tevékenységeket. Minél inkább szűkül a formális, állandó vagy akár alkalmi bérmunka piaca, annál nagyobb lesz az informális munkaformák jelentősége a félproletár háztartások megélhetésében, aminek következtében az osztályalapú etnikai különbségtétel kirekesztő mechanizmusai is megerősödhetnek. Ezek az informális pénzkereseti tevékenységek szimbolikus jelentőséggel is bírnak, hiszen az adott jövedelem nem a munkaadó-munkavállaló között rögzített hierarchikus viszonyból származik, hanem az adott tevékenységet végző személy alkukészségétől függ, s így az autonómia és a viszonyok feletti kontroll érzését nyújtja egy meglehetősen kiszolgáltatott strukturális helyzetben.

Amint láttuk, az informális munkaformák ugyan konjunktúra idején veszítenek jelentőségükből, ám soha nem szorulnak ki teljesen a tartaléksereg-népesség megélhetési portfóliójából. Az informális pénzkereseti tevékenységek többnyire más munkaformákkal kombinálva járulnak hozzá a háztartás megélhetéséhez, így a térbeli, társadalmi mobilitásban betöltött szerepüket azokkal együtt érdemes vizsgálni. Az informális munkaformák jelenléte ugyanakkor éppen a félproletár háztartások strukturális helyzetéből következik, következésképpen, ha különböző módokon is, de társadalmi pozíciójuk fenntartásához járul hozzá.

\section{Összefoglalás}

Tanulmányunkban arra kerestük a választ, hogy a 2008-as gazdasági válság, illetve az azt követő fellendülés milyen változásokat hozott a magyarországi tartaléksereg-népesség megélhetési stratégiában. Írásunk abból indult ki, hogy munkaerő-tartaléksereg sérülékeny strukturális helyzete nem a kapitalista termelésbe való integrálatlanságukból, hanem éppen az integráltság kedvezőtlen módjából fakad. E népesség számára ugyanis csak időlegesen és kedvezőtlen feltételek között érhető el a formális, állandó bérmunka, ezért önfenntartásához 
különböző munkaformákat kell kombinálnia. A tartaléksereg-népesség megélhetési stratégiáinak legfőbb jellemzője a különböző munkaformák közötti cirkuláció, amelyet a gazdasági ciklusok és az egyéni megélhetési stratégiákból adódó választások irányítanak. Tanulmányunkban bemutattuk, hogy miként változik a különböző munkaformák részesedése a tartaléksereg-népesség megélhetésében a válság, majd a gazdasági konjunktúra éveiben. Kutatásunk során arra a következtetésre jutottunk, hogy ugyan a gazdasági fellendülés következtében a formális, állandó bérmunka szerepe felértékelődött a megélhetési stratégiákban, a különböző munkaformák közötti mozgás továbbra is a háztartások önfenntartásának alapját képezi. A munkatípusok közti cirkulációt olyan stratégiaként értelmeztük, amely egyfajta mozgásteret nyújt a globális munkamegosztás előnytelen pozíciójában élők számára.

Tanulmányunkban nem csupán a félproletár háztartások megélhetési stratégiáit vizsgáltuk, hanem ezzel összefüggésben, előnytelen strukturális helyzetük újratermelődését is. Bemutattuk e népesség strukturális helyzetének térbeli és etnikai vonatkozásait: a tartaléksereg általában olyan etnicizált - esetünkben „cigány” - népességet jelent, amely jellemzően periférikus, „értéktelennek” tekintett terekben koncentrálódik. A térbeli és az etnikai dimenzió egyaránt meghatározó szerepet játszik a formális, stabil bérmunkából kiszoruló rétegek előnytelen helyzetének újratermelődésében. A munkaerő-tartaléksereg stratégiáit erőteljesen alakítják a térbeli és etnikai dimenzió fenti összefüggései, a munkaformák közti cirkuláció pedig többnyire együtt jár a térbeli és etnikai kategóriák közötti mozgással is.

Írásunkban a háztartások szemszögéből vizsgáltuk, hogy a különböző munkaformák milyen előnnyel és hátránnyal járhatnak, melyek a legfőbb jellemzőik, valamint hogyan viszonyulnak egymáshoz. Arra a következtetésre jutottunk, hogy a különböző munkaformák (formális, állandó bérmunka, közfoglalkoztatás, alkalmi munka, informális munka) egymáshoz való viszonyukban értelmezhetöek, hiszen továbbra is együtt képezik a háztartások megélhetési stratégiáinak alapjait. A tartaléksereg-népesség állandósult strukturális helyzetét éppen a proletarizáció felé haladó átmenetiség jellemzi, amely együtt jár a munkaformák közti cirkulációval. Ugyanakkor egyes időszakokban, például gazdasági konjunktúra idején a bérmunka erőteljes expanziója révén, úgy tünhet, hogy a társadalmi mobilitás tömegesen megindulhat a formális, állandó bérmunkán keresztül. A történeti tapasztalatok azonban azt mutatják, hogy egy-egy nagy erejü strukturális változás, mint egy világgazdasági válság, átrendeződés, vagy akár a jelenlegi koronavírus-járvány, újra a formális, állandó bérmunka visszaszorulását eredményezheti, amelynek következtében a félproletár háztartások „átmeneti” pozíciója fennmarad. 


\section{Jegyzet}

1 A tanulmányban felhasznált empirikus adatok összesen nyolc terepmunka tapasztalatait foglalják magukban. A terepmunkák helyszíneiként Észak-Magyarországon a Mezőkövesdi és Encsi járás, az Észak-Alföldön a Karcagi, Nagykállói, Vásárosnaményi járás, valamint a Dél-Dunántúlon a Marcali, Tamási és Komlói járás szolgáltak.

\section{Köszönetnyilvánítás}

A tanulmány az MTA Kiválósági Együttmúködési Program Mobilitás Kutatási Centrum projektje keretében készült.

Kovai Cecília kutatását az NKFIH az „Állami beavatkozások és fejlesztői tevékenységek hatása hátrányos helyzetű roma közösségekre" című (PD 121058 számú) projekt támogatása révén tette lehetővé.

Külön köszönet illeti a KRTK Regionális Kutatások Intézete Közép- és Észak- magyarországi Tudományos Osztályának kollégáit és a Helyzet Műhely tagjait, akik a kéziratról tartott viták során értékes hozzászólásaikkal járultak hozzá a tanulmány végső megszövegezéséhez.

\section{Irodalom}

Ábrahám Á., Kertesi G. (1996): A munkanélküliség regionális egyenlőtlenségei Magyarországon. A foglalkoztatási diszkrimináció és az emberi tőke váltakozó szerepe. Közgazdasági Szemle, 7-8., 653-681.

Apró A. Z. (2004): Szegregáció-Munkaerőpiac- Foglalkoztatási esélyegyenlőség. Pécsi Tudományegyetem, Pécs

Asztalos-Morell, I. (2014): Workfare with human face? Metszetek, 4., 3-24.

Babusik F. (2007): Magyarországi cigányság-strukturális csapda és kirekesztés. Esély, 1., 3-23.

Bakó T., Lakatos J. (2019): A magyarországi munkapiac 2018-ban. Fazekas K., Csillag M., Hermann Z., Scharle Á. (szerk.): Munkaerőpiaci tükör 2018. Közgazdasági és Regionális Tudományi Kutatóközpont, Budapest, 15-32.

Bernáth A. (2014): Leszakadóban: Romák társadalmi helyzete a mai Magyarországon. In: Kolosi T., Tóth I. Gy. (szerk): Társadalmi riport 2014. TÁRKI, Budapest, 344-362.

Bihari Zs., Kovács K. (2016): Lejtők és csúszdák, avagy a foglalkoztatási esélyek térbeli egyenlőtlensége az ezredfordulón. Tér és Társadalom, 4., 49-66. https://doi.org/10.17649/TET.20.4.1077

Boatcă, M. (2015): World-Systems Analysis and the Feminist Subsistence Perspective. In: Global Inequalities Beyond the Occidentalism. Ashgate Publishing Company, 121-138.

Bourgois, P. (1995): In Search of Respect: Selling Crack in El Bario. Cambridge University Press, Cambridge

Bródy L. S.. Pósfai Zs. (2020): A háztartások eladósodása Magyarországon. Periféria Közpolitikai és Kutatóközpont, Budapest https://mek.oszk.hu/20600/20618/20618.pdf (Letöltés: 2020.08.03.)

Czirfusz M. (2015): A közfoglalkoztatás térbeli egyenlőtlenségei. In: Fazekas K., Varga J. (szerk.): Munkaerőpiaci tükör 2014. MTA Közgazdaság- és Regionális Tudományi Kutatóközpont Közgazdaságtudományi Intézet, Budapest, 126-138.

Czirfusz M., Ivanics Zs., Kovai C., Meszmann T. (2019): A magyarországi munkásság a hosszú lejtmenetben. Fordulat, 26., 142-170.

Csányi G., Gagyi Á., Kerékgyártó Á. (2018): Társadalmi reprodukció. Az élet újratermelése a kapitalizmusban. Fordulat, 24., 5-29. 
Csoba J. (2010): „Segély helyett munka.” A közfoglalkoztatás formái és sajátosságai. Szociológiai Szemle, 1., 26-50.

Danyi G., Vigvári A. (2019): Túlélés, ellenállás, adaptáció: informális gyakorlatok Magyarországon és Lengyelországban. Replika, 110/ 1., 11-31. https://doi.org/10.32564/110.2

Dunaway, W. A. (2018): Félproletár háztartás a modern világrendszer longue durée-je folyamán. Fordulat, 24., 53-88.

Durst J. (2008): "Bárók”, patrónusok versus „komák”: Eltérő fejlődési utak az aprófalvakban. In: Váradi M.M. (szerk.): Kistelepülések lépéskényszerben. Új Mandátum, Budapest, 232-280.

Durst, J. (2015): New Redistributors in Times of Insecurity: Different Types of Informal Lending in Hungary. In: Brazzabeni, M., Cunha, M. I., Fotta, M. (eds.): Gipsy Economy: Romani Livelihoods and Notions of Worth in the 21st Century. Berghahn Books, New York, 49-67.

Éber M.Á., Gagyi Á., Gerőcs T., Jelinek Cs., Pinkasz A. (2014): 1989: Szempontok a rendszerváltás globális politikai gazdaságtanához. Fordulat, 21., 64-86.

Éber M.Á. (2020): A csepp. A félperifériás magyar társadalom osztályszerkezete. Napvilág, Budapest

Efremova, G. (2012): Integralist Narratives and Redemptive Anti-Gypsy Politics in Bulgaria. In: Stewart, M. (ed.): The Gypsy "Menace": Populism and the New Anti-Gypsy Politics. Hurst and Company, London, 43-66.

Fazekas K. (1997): Válság és prosperitás a munkaerőpiacon. A munkanélküliség regionális sajátosságai Magyarországon 1990-1996 között. Tér és Társadalom, 4., 9-24. https://doi.org/10.17649/ TET.11.4.447

Ferge Zs.(2017): Magyar társadalom- és szociálpolitika 1990-2015. Osiris Kiadó, Budapest

Fleck G., Orsós J., Virág T. (2000): Élet a Bodza utcában. In: Kemény I. (szerk): Romák/cigányok és a láthatatlan gazdaság. Osiris, Budapest, 80-138.

Fleck G., Messing V. (2009): A roma foglalkoztatáspolitika alakváltozásai. In: Fazekas K., Lovász A., Telegdy Á. (szerk.): Munkaerőpiaci tükör, 2009. Országos Foglalkoztatási Közalapítvány, MTA Közgazdaságtudományi Intézet, Budapest, 82-96.

Gerő M., Vigvári A. (2019): Közfoglalkoztatás, redisztribúció és helyi hatalom. Esély, 2., 3-30.

Grill, J. (2015):”Endured Labour” and „Fixing up” Money. In: Brazzabeni, M., Cunha, M.I., Fotta, M. (eds.): Gipsy Economy: Romani Livelihoods and Notions of Worth in the 21st Century. Berghahn Books, New York, 88-106.

Grill, J. (2018): Re-learning to labour?'Activation Works' and new politics of social assistance in the case of Slovak Roma. Journal of Royal Anthropological Institute, 24., 105-119. https://doi.org/ 10.1111/1467-9655.12802

Han, C. (2018): Precarity, Precariousness, and Vulnerability. Annual review of Anthropology, 47., 331-343. https://doi.org/10.1146/annurev-anthro-102116-041644

Hart, K. (1973): Informal income opportunities and urban employment in Ghana. Journal of Modern African Studies, 11., 61-89.

Havas G. (1983): Foglalkozásváltási stratégiák különböző cigány közösségekben. In: Cigányvizsgálatok. Művelődéskutató Intézet, Budapest, 181-222.

Jávor K., Molnár M., Szabó P., Sárkány M. (2000): A falusi társadalom a szocializmus időszakában In.: Paládi-Kovács A. (szerk.): Magyar néprajz nyolc kötetben: Társadalom VIII., Akadémiai Kiadó, Budapest, 977-1006.

Kálmán J. (2015): A közfoglalkoztatási programok háttere és nemzetközi tapasztalatai. In: Fazekas K., Varga J. (szerk.): Munkaerőpiaci Tükör 2014, MTA KRTK Közgazdaságtudományi Kutatóintézet, Budapest, 42-58.

Katona I. (1965): Átmeneti bérmunkaformák. In: Szabó I. (szerk.): A parasztság Magyarországon a kapitalizmus korában: 1848-1914. II. kötet. Akadémiai Kiadó, Budapest, 382-432.

Kemény I. (1972): A magyar munkásosztály rétegződése. Szociológia, 1., 36-48.

Kertesi G. (2005): A társadalom peremén. Romák a munkaerőpiacon és az iskolában. Osiris Kiadó, Budapest

Kolosi T., Tóth I. Gy. (2008): A rendszerváltás nyertesei és vesztesei - generációs oldalnézetből: Tíz állítás a gazdasági átalakulás társadalmi hatásairól. In: Kolosi T., Tóth I. Gy. (szerk.): Társadalmi riport 2008. TÁRKI, Budapest, 15-45. 
Kovai C. (2016): Önellátó függőség. In: Kovács K. (szerk.): Földből élók. Polarizáció a magyar vidéken. Argumentum Kiadó, Budapest, 137-160.

Kovai C. (2017): A cigány-magyar különbségtétel és a rokonság. L'Harmattan, Budapest

Kovai, C. (2019): Permanent wage labour as a norm. Workfare policy and everyday experiences of precariousness in a small Hungarian former industrial town. socio.hu: Társadalomtudományi Szemle, Special Issue, 143-161. https://doi.org/10.18030/socio.hu.2019en.142

Kovách I. (2012): A vidék az ezredfordulón: A jelenkori magyar vidéki társadalom szerkezeti és hatalmi változásai. Argumentum Kiadó, Budapest

Köllő J. (2009): A pálya szélén. Iskolázatlan munkanélküliek a posztszocialista gazdaságban. Osiris Kiadó, Budapest

Köllő J., Nyírő Zs., Tóth I. J. (2017): Az alapvető hiányindikátorok alakulása. In: Fazekas K., Köllő J. (szerk.): Munkaerőpiaci Tükör 2016. MTA Közgazdaság- és Regionális Tudományi Kutatóközpont, Közgazdaságtudományi Intézet, Budapest, 63-72.

Ladányi J., Szelényi I. (1998):Szuburbanizáció és gettósodás. In: Kovalcsik K. (szerk): Tanulmányok a cigányság társadalmi helyzete és kultúrája köréból. IFA-OM-ELTE, Budapest, 185-206.

Ladányi J., Szelényi I. (2004): A kirekesztettség változó formái. Napvilág Kiadó, Budapest

Lőcsei H. (2010): A gazdasági világválság hatása a munkanélküliség területi egyenlőtlenségeire. In: Fazekas K., Molnár Gy. (szerk.): Munkaerőpiaci Tükör 2010. MTA Közgazdaságtudományi Intézet, Országos Foglalkoztatási Közalapítvány, Budapest, 146-161.

Márkus I. (1973): Az utóparasztság arcképéhez. Szociológia, 1., 56-67.

Meszmann T. (szerk.) (2019): Fókuszban Kecskemét: Munkafeltételek a dél-alföldi autóiparban. Budapest, Vasas Szakszervezeti Szövetség. https://www.fes-budapest.org/fileadmin/user_upload/dokumente/pdf-dateien/Kecskemet20190618.pdf (Letöltés: 2020. 08. 04.)

Millar, K. M. (2014): „Precarious Present”: Wageless Labor and Disrupted Life in Rio de Janeiro, Brazil. Cultural Anthropology, 29., 32-53. DOI: 10.14506/ca29.1.04

Millar, K. M. (2018): Reclaiming the Discarded: Life and Labor on Rio's Garbage Dump. Duke University Press, Durham

Molnár, Gy., Bazsalya, B., Bódis, L.,Kálmán, J. (2019): Public works in Hungary: actors, allocation mechanisms and labour market mobility effects. socio.hu: Társadalomtudományi Szemle, Special Issue, 117-142. DOI: 10.18030/socio.hu.2019en.116

Nemes Nagy J., Ruttkay É. (1989): A második gazdaság földrajza. OT TGI, Budapest

Nemes Nagy J., Németh N. (2003): A „hely" és a "fej": a regionális tagoltság tényezői az ezredforduló Magyarországán. MTA Közgazdaságtudományi Kutatóközpont (KTK), Budapest

Németh, K. (2019): Trapped in the past? The reproduction of poverty and marginality in a Hungarian manorial village. Sociologia Ruralis, 3., 419-446. https://doi.org/10.1111/soru.12249

Németh K. (2020): “Cseberből vederbe" - A mikromobilitás mintázatai egy marginalizált mikrotérben. Tér és Társadalom, 3., 90-113. https://doi.org/10.17649/TET.34.3.3279

Petrovici, N., Rat, C., Simionca, A., Vincze, E. (2019): Introduction: Racialized Labour of Dispossessed as an Endemic Feature of Capitalism. In: Vincze, E., Petrovici, N., Rat, C., Picker, G. (Eds.):: Racialized Labour in Romania: Spaces of Marginality at the Periphery of Global Capitalism. Palgrave MacMillan, 1-37.

Quijano, A. (2000): Coloniality of power and Eurocentrism in Latin America. International Sociology, 2.. 215-232. https://doi.org/10.1177/0268580900015002005

Rajaram, P. K. (2018): Refugees as Surplus Population: Race, Migration and Capitalist Value Regimes. New Political Economy, 23., 627-639. https://doi.org/10.1080/13563467.2017.1417372

Sanyal, K. (2007): Rethinking capitalist development: primitive accumulation, governmentality and postcolonial capitalism. Routledge, New Delhi

Scharle Á. (2012): Jóléti és munkanélküli-ellátások. In: Fazekas K., Scharle Á.(szerk): Nyugdíj, segély, közmunka. A magyar foglalkoztatáspolitika két évtizede. Szakpolitikai Elemző Intézet - MTA KRTK Közgazdaságtudományi Intézet, Budapest, 134-142.

Schwertner J. (1994): Parázsló munkaerőpiac. Tér és Társadalom, 1-2., 59-82. https://doi.org/ 10.17649/TET.8.1-2.296

Szalai E. (2001): Gazdasági elit és társadalom a magyarországi újkapitalizmusban. Aula Kiadó, Budapest 
Szalai J. (2007): Nincs két ország...? Társadalmi küzdelmek az állami (túl)elosztásért a rendszerváltás utáni Magyarországon. Osiris Kiadó, Budapest

Szikra, D.(2014): Democracy and welfare in hard times: The social policy of the Orbán Government in Hungary between 2010 and 2014. Journal of European Social Policy, 5., 456-500. https://doi.org/ $10.1177 / 0958928714545446$

Szőke, A. (2015): A 'Road to Work'? The reworking of deservedness, social citizenship and public work programmes in rural Hungary. Citizenship Studies, 6-7., 734-750. http://dx.doi.org/ 10.1080/13621025.2015.1053790

Szombati, K. (2018): The Revolt of the Provinces. Anti-Gypsyism and Right-Wing Politics in Rural Hungary. Berghan Books, New York

Tóth P. (1997): Falusi cigányság és az informális szektor. Magyar Tudomány, 6., 690-697.

Váradi M. M. (2016): Értékteremtő közfoglalkoztatás periférikus vidéki terekben. Esély, 1., 30-56.

Váradi M. M., Virág T. (2017): A térbeli kirekesztés változó mintái vidéki terekben. Szociológiai Szemle, 1., 89-113.

Váradi M. M. (2020): Az (im)mobilitás dinamikái vidéki terekben - szakirodalmi kitekintés, empirikus kiegészítésekkel. Tér és Társadalom, 3., 114-141. https://doi.org/10.17649/TET.34.3.3285

Van der Linden, M. (2001): Global Labor History and "the Modern World-System": Thoughts at the Twenty-Fifth Anniversary of the Fernand Braudel Center. International Review of Social History, 3., 423-459.

Vidra Zs. (2013a) A szakképzetlen bérmunka szerepe a falusi romák megélhetési stratégiáiban. In: Kovács K., Váradi M. (szerk): Hátrányban vidéken. Argumentum Kiadó, Budapest, 57-74.

Vidra Zs. (2013b): Formális és informális megélhetési kényszerek. In: Kovács É., Vidra Zs., Virág T. (szerk): Kint és bent: lokalitás és etnicitás a peremvidékeken. L'Harmattan, Budapest, 57-77.

Vigvári A. (2013): Utcaharc: egyeztetési eljárások az egyik tiszakerecsenyi utcában. In: Kovács É., Vidra Zs., Virág T. (szerk.): Kint és bent: Lokalitás és etnicitás a peremvidékeken. L'Harmattan, Budapest, 303-319.

Vigvári A. (2015): Vissza a tanyákra - egy cigány család újrakezdési esélyi a szabolcsi pusztai világban. In: Virág T. (szerk.): Törésvonalak. Szegénység és etnicitás vidéki terekben. Argumentum Kiadó, Budapest, 211-228.

Vigvári, A., Gerőcs, T. (2017): The Concept of 'Peasant Embourgeoisement' in the Perspective of Different Historical Conjunctures. Studia Universitatis Babes-Bolyai Sociologia, 1., 85-104. https:// doi.org/10.1515/subbs-2017-0006

Virág T. (2010): Kirekesztve. Falusi gettók az ország peremén. Akadémiai Kiadó, Budapest

Virág T., Zolnay J. (2010): Csapdába került önkormányzatok, csapdában tartott szegények - közfoglalkoztatása Csereháton. Esély, 1., 119-130.

Wallerstein, I. (2000): The Essential Wallerstein. The New Press, New York

Waquant L. (2008): Urban Outcast: A Comparative Sociology of Advanced Marginality. Polity Press, London

Wacquant, L. (2012): A Janus-Faced Institution of Ethnoracial Closure: A Sociological Specification of the Ghetto. In: Hutchison, R. Haynes, B. D. (eds): The Ghetto. Contemporary Global Issues and Controversies. Westview Press, 1-32. 